\title{
Chapter 9 \\ Decomposing Spatial Inequality \\ in Sri Lanka: A Quantile Regression Approach
}

\author{
Thusitha Kumara
}

\begin{abstract}
This paper uses the Blinder and Oaxaca decomposition method and its recent expansion (Machado and Mata) to examine whether well-being gaps between urban (richer regions) and rural (poorer regions) areas are the result of (i) regional/spatial differences in household characteristics or (ii) differences in location-specific returns to these characteristics. The data used in this study are from the Household Income and Expenditure Surveys for 2006/2007 and 2009/2010. The analysis suggests that the existence of barriers, such as remoteness and poor access to markets, that prevents lagging regions from being absorbed into the modern sector or growing region plays a larger role in perpetuating spatial inequality, especially for the poor, than disparities in household characteristics (endowments) between regions and sectors.
\end{abstract}

Keywords Spatial inequality - Quantile regression • Inequality decomposition • Sri Lanka

\subsection{Introduction}

Inequality increased during the last decade of the twentieth century in both developing and developed countries (World Bank 2005a). In the People's Republic of China, the Russian Federation, India, Mexico, South Africa, and Viet Nam, as in many other developing and transition countries, this increase in inequality was accompanied by spatial and regional disparities in economic activities, and income and social indicators (Kanbur and Venables 2005). This rising trend in overall

\footnotetext{
T. Kumara $(\bowtie)$

Department of Economic Development and Policies, Graduate School of International

Cooperation Studies, Kobe University, Kobe, Japan

e-mail: thusitha@uwu.ac.lk
} 
inequality was also evident in South Asia which had long been characterized by relatively low and stable levels of inequality. Recent evidence shows that there was a sizeable increase in inequality in Bangladesh, India, Nepal, and Sri Lanka in the late 1980s and 1990s (World Bank 2005a). For example, inequality in consumption expenditure in Sri Lanka rose from a Gini coefficient of 0.32 in 1990 to 0.40 in 2009/2010, possibly the sharpest increase in inequality in its recent history, making its distribution more unequal than many of its East Asian neighbors, and on par with Bangladesh and Nepal. ${ }^{1}$

Rising inequality has two components. The first is within the fast-growing modern industrial sector and region. This is to a large extent vertical inequality, driven by asset and skill differences. ${ }^{2}$ The second is between the fast-growing modern industrial sectors and regions, on the one hand, and the traditional agricultural sectors and regions, on the other. What is striking about the latter component of inequality is that two individuals with identical productive characteristics (schooling, skills, training, experience) could face differential returns to their endowments, depending on where they live. These differentials encourage individuals in the low-returns sector or region to move or migrate into the high-returns sector, eventually equalizing returns in both sectors. Cheaper labor in the lowreturns regions may also attract capital (firms and entrepreneurs) to move to these areas. But if these differentials persist over time, it suggests that there are barriers (failures) that prevent the traditional sector or lagging region from being absorbed into the modern sector. This argument is well presented in the World Development Report 2009: Reshaping Economic Geography (World Bank 2008) which argues that higher densities, shorter distances, and lower divisions are essential for the development of an economy. Economic geography suggests that this growth will be initially unbalanced and lead to widening disparities. However, spatial transformations that reduce distance and divisions, and calibrate densities of economic growth with densities of poverty, may lead to inclusive growth and lower inequality. Hence, policies to reduce inequality need to identify the sources of spatial disparities-if there are gaps in characteristics, it is important to improve endowments of the households; if barriers exist between lagging and leading regions, these barriers need to be removed.

Although Sri Lanka recorded moderate economic growth during the last decade, the regions that are far away from its economic capital, Colombo, tend to be significantly poorer than the areas closer to Colombo. Though a number of regional development programs have been implemented by successive governments, living standards of the people in the remote areas continue to fall significantly behind their urban counterparts. This suggests that a better understanding of the causes of inequality is essential for effective policy formulation.

\footnotetext{
1 The Gini coefficient of per capita consumption expenditure of Bangladesh was 0.41 in 2000 as compared to 0.30 in 1991; in Nepal, it increased from 0.34 in 1995/1996 to 0.39 in 2003/2004.

2 This does not preclude the existence of groups within the fast-growing sector (women, minorities) who experience horizontal inequality.
} 
Programmes and policies in Sri Lanka's current development strategy may be divided into three categories. The first includes the improvement of facilities in schools, establishment of new universities in poor areas, and the spread of information technology facilities (provision of an IT center to each district secretariat), all of which pertain to improving household and community human capital endowments. The second category includes the improvement of roads (primarily rural roads), irrigation systems (small-scale tanks), and promotion of rural industries (primarily via small-, large-, and medium-scale enterprises). These could be considered as efforts to improve location-specific returns, but keep the focus at the community or regional level. The last set of programs which is expected to have an impact on reducing disparities in location-specific returns focuses primarily on transport infrastructure, such as the Colombo-Kandy expressway and the Southern Highway, which improves access to and mobility between regions, and is likely to reduce regional gaps in location-specific returns.

This paper uses a standard methodology and its recent expansion to examine whether well-being gaps between urban (richer regions) and rural (poorer regions) areas are the result of (i) regional/spatial differences in household characteristics or (ii) differences in location-specific returns to these characteristics. The purpose of the paper is to examine the role of location-specific returns to households' productive characteristics, and the extent to which they contribute to the gaps in consumption across the distribution of consumption.

\subsection{Analytical Framework}

This study employs a conventional decomposition method of measuring discrimination and its quantile regression extension to analyze spatial inequality in Sri Lanka. In this section, we (1) explain the decomposition as it applies to average gaps between locations, (2) describe quantile regression, and (3) present the extension of the decomposition to quantile regression estimates.

Wan (2007) discusses that inequality between urban and rural areas cannot be totally explained by the geographical division between the urban and rural areas of a particular economy as assumed by the conventional inequality decomposition techniques. Many other factors such as differences in human capital and differences in demographic factors also affect the determination of urban and rural inequalities. But the traditional inequality decomposition techniques do not include control variables for these factors. The decomposition of inequality using regression provides a neat solution for this (Wan 2007). The regression-based decomposition allows for the inclusion of control variables as well as other socioeconomic determinants of inequality rather than the geographical location (Gunatilaka and Chotikapanich 2009). Furthermore, regression-based decomposition analysis enables identification and quantification of the determinants of inequality (Wan 2002) which are important and of interest to economists and policy makers. 
The seminal works of Blinder (1973) and Oaxaca (1973) provide the basic roots for regression-based decomposition techniques. The Blinder-Oaxaca decomposition is extensively applied in decomposition analysis, and several extensions have been developed recently (Fortin et al. 2011). The intuition behind the conventional method of measuring discrimination, developed independently by Blinder (1973) and Oaxaca (1973), is that in the absence of discrimination, the estimated effects of individuals' observed characteristics on their wages are identical for groups of individuals. Similarly, in the absence of location-specific returns, the estimated effects of a household's observed characteristics on some measure of household well-being (such as income or consumption) are identical for each location. The estimated income gap can be decomposed as follows:

$$
\text { In } y^{* \text { urban }}-\text { In } y^{* \text { rural }}=X^{* \text { rural }}\left(\beta^{\text {urban }}-\beta^{\text {rural }}\right)+\left(X^{* \text { urban }}-X^{* \text { rural }}\right) \beta^{\text {urban }}
$$

where $\ln y$ is a measure of household income or consumption, $X$ is a vector of income-generating characteristics for the $i$ th household, and $\beta$ is a vector of coefficients. The asterisks denote mean or average. The first term on the right-hand side is the portion due to differences in coefficients $\left(\beta^{\text {urban }}-\beta^{\text {rural }}\right)$, evaluated at the same set of average income-generating characteristics $X^{* \text { rural }}$, in this case the rural (poorer region). The second term is the portion of the gap attributed to differences in average earnings-generating characteristics $\left(X^{* \text { urban }}-X^{* \text { rural }}\right)$, weighted by the urban (richer region) returns structure. ${ }^{3}$

If there were no location-specific effects, $\beta^{\text {urban }}=\beta^{\text {rural }}$, i.e., endowments in both locations yield similar returns, the first term would be zero, and any regional disparities would be completely explained by differences in characteristics of households in the two locations, $X^{* \text { urban }}-X^{* \text { rural }}$. With no disparity in returns, migration would be low or zero.

The Blinder-Oaxaca decomposition is based on ordinary least squares (OLS) regression which assumes that the effect of the regressors does not vary along the conditional distribution of the dependent variable. For example, the effect of schooling on household welfare is assumed to be the same at the bottom of the welfare distribution as it is at the top. If, however, these effects do vary along the distribution of household welfare, quantile regressions, which yield models for different percentiles of the distribution, provide a parsimonious way of describing the whole distribution (Martins and Pereira 2004). The $\theta$ th quantile of $y_{i}$ conditional on $\boldsymbol{X}_{i}$ is given by

$$
Q_{\theta}\left(y_{i} \mid \boldsymbol{X}_{\boldsymbol{i}}\right)=\boldsymbol{X}_{\boldsymbol{i}} \beta_{\theta}, \theta \in(0,1) \quad(i=1, \ldots, I)
$$

where the coefficient $\beta_{\theta}$ is the slope of the quantile line, giving the effect of changes in $X$ on the $\theta$ th conditional quantile of $y$. As shown by Koenker and Basset (1978), the quantile regression estimator of $\beta_{\theta}$ solves the following minimization problem.

\footnotetext{
${ }^{3}$ The decomposition may also be expressed in terms of average urban endowment $X^{* u r b a n}$ and rural (poorer regions) returns structure $\beta^{\text {rural }}$.
} 


$$
\beta_{\theta}=\arg \min \left[\sum_{i: y_{i} \geq X_{i} \beta} \theta\left|y_{i}-X_{i} \beta\right|+\sum_{i: y_{i} \geq X_{i} \beta} 1-\theta\left|y_{i}-X_{i} \beta\right|\right]
$$

It is easily seen that for the median $[\theta=0.5]$, the quantile regression minimizes the sum of absolute deviations.

Machado and Mata (2005) combine quantile regression with a bootstrap approach and derive the following decomposition, which is analogous to the Blinder-Oaxaca decomposition in Eq. 9.1:

$$
\begin{aligned}
Q_{\theta}\left(y^{\text {urban }}\right)-Q_{\theta}\left(y^{\text {rural }}\right)= & {\left[Q_{\theta}\left(X_{i}^{\text {rural }} \beta^{\text {urban }}\right)-Q_{\theta}\left(X_{i}^{\text {rural }} \beta^{\text {rural }}\right)\right] } \\
& +\left[Q_{\theta}\left(X_{i}^{u \text { rban }} \beta^{\text {urban }}-Q_{\theta}\left(X_{i}^{\text {rural }} \beta^{\text {urban }}\right)\right]+\right.\text { residual }
\end{aligned}
$$

The first term on the right-hand side is the contribution of the coefficients (returns effect), and the second term is the contribution of the covariates (covariate effect) to the difference between the $\theta$ th quantile of the urban (rich region) distribution of consumption and the $\theta$ th quantile of the rural (poor region) consumption distribution. The residual term comprises the simulation errors which disappear with more simulations, the sampling errors which disappear with more observations, and the specification error induced by estimating linear quantile regression (Melly 2005). It is assumed that the linear quantile model is correctly specified.

The Machado-Mata (2005) decomposition is interpreted similar to the BlinderOaxaca decomposition. Since the decomposition can be conducted at any percentile of the consumption distribution, it reveals whether the relative importance of covariates and coefficients varies along the distribution.

\subsection{Data and Variables}

The data used in this study are from the Household Income and Expenditure Surveys (HIES) for 2006/2007 and 2009/2010. These national surveys, however, do not cover the Northern and Eastern Provinces of Sri Lanka. ${ }^{4}$ The primary sampling unit is the household, and the sample size ranges from 17,037 households in $2006 / 2007$ to 19,958 households in 2009/2010. ${ }^{5}$ Both surveys comprise 12 monthly rounds that capture seasonal variations. The sample design allows for

\footnotetext{
4 These two provinces are the two most severely affected by the armed conflict with the separatist LTTE movement. However, these two provinces were excluded from the study due to nonavailability of comparable data.

5 The sample size of the HIES (DCS) was around 20,100 households in both the survey years. The sample size of this study was reduced to the above numbers due to data cleaning.
} 
subgroup analysis at the province and district levels. In the urban-rural analysis, the estate sector was subsumed under the rural sector for the purpose of decomposition. These data sets have been used in poverty analysis and exhibit no major problems in terms of inconsistency and inaccuracy (World Bank 2005b, 2007a, b).

The primary measure of well-being in this paper is real household consumption expenditure per capita. Consumption data are used in preference to income data for several reasons. Consumption is a direct measure of achieving or fulfilling basic needs and a better measure of current welfare, incorporating consumption smoothing by households within a given period of time and over the life cycle (Duclos and Araar 2006; Deaton 1997). Consumption data are more easily observable than income data. The latter are vulnerable to underreporting due to the innate features of income reporting, that is, fewer formal income receivers, seasonal and unrecorded income sources, and the diversified nature of earnings (Heltberg 2003). For these reasons, consumption is typically used in the analysis of poverty and inequality.

The measure of consumption expenditure includes over 400 items of household consumption. Food consumption is reported in calendar style, for a week, while non-food consumption is reported for the past month, 6 or 12 months. Consumption on all items is converted to monthly consumption. Reported values are of the amount consumed, which includes goods and services purchased as well as home-produced goods and services. Although the latter comprises a substantial proportion of household consumption, and problems of using imputed values are well known (Deaton 1997), the values used are consistent over time, unlike the problems raised by the use of different (and possibly inconsistent) values in transition countries (Benjamin et al. 2005; Ravallion 2005). The rental value of owned housing is also imputed in the data set. The household is defined as 'one or more persons living together and having common arrangements for food and other essentials of living' (Department of Census and Statistics 1987).

Spatial and temporal price indices are computed using district-level nominal poverty lines published by the $\mathrm{DCS}^{6}$ and are constructed at the district level. These are constructed for each data set, allowing spatial prices to vary (as they do) over time, and are later adjusted with regard to temporal variations.

Two categorizations of spatial location are used in the decompositions derived in this paper. The first is the conventional urban and rural (the estate sector is subsumed into the rural) distinction. The second categorization classifies the economically better-off Western Province (WP), which has all the characteristics of a leading region, as the richer region, and includes all other regions in the poorer region category. While this classification ignores the variation among other regions, it is adopted because the methodology requires a binary classification. The gap in consumption between the WP and the other regions is sufficiently large to justify such a classification.

${ }^{6}$ http://www.statistics.gov.lk/poverty/OfficialPovertyLineBuletin.pdf (accessed on 23 January 2008). 
Table 9.1 List of variables

\begin{tabular}{|c|c|}
\hline Variable & Description \\
\hline PCE & Log real expenditure per capita \\
\hline AEM & Dummy for engaged in agricultural work $(\mathrm{No}=0)$ \\
\hline EMP & Number of employed members in the family \\
\hline HAG & Household head's age \\
\hline he & Household head's sex \\
\hline his & Household size \\
\hline \multirow[t]{2}{*}{ DEP } & Number of dependants in the family \\
\hline & Dummies for household head's race $($ Sinhala $=0$ ) \\
\hline HRD1 & Tamil \\
\hline \multirow[t]{2}{*}{ HRD2 } & Muslim or other \\
\hline & $\begin{array}{l}\text { Dummies for the most educated member ( } \mathrm{No} / \text { primary } \\
\text { education }=0 \text { ) }\end{array}$ \\
\hline HED1 & Junior secondary (Grade 7-9) \\
\hline HED2 & GCE O/L \\
\hline HED3 & GCE A/L \\
\hline \multirow[t]{2}{*}{ HED4 } & Tertiary (graduate or vocational) \\
\hline & Dummies for the province (Western Province $=0$ ) \\
\hline PRD1 & Dummy for province: Central Province \\
\hline PRD2 & Dummy for province: Southern Province \\
\hline PRD3 & Dummy for province: North Western Province \\
\hline PRD4 & Dummy for province: North Central Province \\
\hline PRD5 & Dummy for province: Uva Province \\
\hline PRD6 & Dummy for province: Sabaragamuwa Province \\
\hline
\end{tabular}

Regressors used in the model (Table 9.1) include (1) factors that influence the household's earning ability, such as the number of employed members in the household, the sector of employment (whether any household members were engaged in agricultural work), the household head's age, and household human capital (the highest level of education attained by any member of the household) ${ }^{7}$; (2) demographic features of the household that influence the level of consumption per capita such as the number of dependents (number of household members aged below 15 years and above 65 years); (3) other demographic features such as the household head's gender and ethnicity; and (4) location variables to control for regional variation within urban and rural sectors (only in the urban and rural specification).

\footnotetext{
7 Ministry of Education of Sri Lanka categorizes the education system in Sri Lanka as Primary: Year 1-5, Junior Secondary: Year 6-9, Senior Secondary: Year 10-11 (GCE O/L), College: Year 12-13(GCE A/L) and Tertiary: University and Vocational (http://www.moe.gov.lk/modules.php?n ame $=$ Contentandpa $=$ showpageandpid $=7$ ).
} 
Table 9.2 Descriptive statistics, 2009/2010

\begin{tabular}{|c|c|c|c|c|c|c|c|c|c|c|}
\hline \multicolumn{11}{|l|}{$2009 / 2010$} \\
\hline & \multicolumn{2}{|l|}{ Urban } & \multicolumn{2}{|l|}{ Rural } & \multicolumn{2}{|c|}{$\begin{array}{l}\text { Western } \\
\text { Province }\end{array}$} & \multicolumn{2}{|c|}{$\begin{array}{l}\text { Other } \\
\text { Provinces }\end{array}$} & \multicolumn{2}{|c|}{ National } \\
\hline & Mean & St. De. & Mean & St. De. & Mean & St. De. & Mean & St. De. & Mean & St. De. \\
\hline $\begin{array}{l}\text { Real expenditure } \\
\text { per capita }\end{array}$ & 9,041 & 11,656 & 6,545 & 5,799 & 8,738 & 8,835 & 6,539 & 7,184 & 7,184 & 7,807 \\
\hline $\begin{array}{l}\text { Engaged in } \\
\text { agricultural work }\end{array}$ & 8.00 & - & 35.93 & - & 12.07 & - & 34.88 & - & 28.55 & - \\
\hline $\begin{array}{l}\text { Number of } \\
\text { employed } \\
\text { in the family }\end{array}$ & 1.31 & 0.88 & 1.41 & 0.90 & 1.45 & 0.91 & 1.36 & 0.88 & 1.39 & 0.89 \\
\hline Head's age & 51.00 & 14.00 & 50.68 & 14.08 & 51.76 & 14.13 & 50.39 & 14.01 & 51.76 & 14.06 \\
\hline $\begin{array}{l}\text { Male household } \\
\text { head }^{\text {a }}\end{array}$ & 72.67 & - & 77.11 & - & 76.27 & - & 75.81 & - & 75.94 & - \\
\hline $\begin{array}{l}\text { Head's race: } \\
\text { Sinhala }^{\text {a }}\end{array}$ & 57.90 & - & 74.90 & - & 81.27 & - & 66.29 & - & 70.41 & - \\
\hline $\begin{array}{l}\text { Head's race: } \\
\text { Tamil }^{\mathrm{a}}\end{array}$ & 22.61 & - & 17.43 & - & 10.49 & - & 21.95 & - & 18.80 & - \\
\hline $\begin{array}{l}\text { Head's race: } \\
\text { Muslim or other }{ }^{\mathrm{a}}\end{array}$ & 19.50 & - & 7.66 & - & 8.23 & - & 11.76 & - & 10.29 & - \\
\hline Household size & 4.22 & 1.83 & 3.4 & 1.6 & 4.14 & 1.7 & 4.02 & 1.69 & 4.05 & 1.7 \\
\hline $\begin{array}{l}\text { Number of } \\
\text { dependents } \\
\text { in the family }\end{array}$ & 1.31 & 1.18 & 1.25 & 1.13 & 1.24 & 1.13 & 1.28 & 1.15 & 1.27 & 0.43 \\
\hline $\begin{array}{l}\text { Most educated } \\
\text { member: no } \\
\text { schooling/ } \\
\text { primary }^{\mathrm{a}}\end{array}$ & 4.19 & - & 8.25 & - & 3.52 & - & 8.56 & - & 7.18 & - \\
\hline $\begin{array}{l}\text { Most educated } \\
\text { member: junior } \\
\text { secondary }^{\mathrm{a}}\end{array}$ & 13.22 & - & 16.89 & - & 12.77 & - & 17.11 & - & 15.92 & - \\
\hline $\begin{array}{l}\text { Most educated } \\
\text { member: GCE } \\
\text { O/L }{ }^{a}\end{array}$ & 38.06 & - & 41.63 & - & 40.50 & - & 40.76 & - & 40.69 & - \\
\hline $\begin{array}{l}\text { Most educated } \\
\text { member: GCE } \\
\mathrm{A} / \mathrm{L}^{\mathrm{a}}\end{array}$ & 36.03 & - & 28.05 & - & 36.02 & - & 27.94 & - & 30.16 & - \\
\hline $\begin{array}{l}\text { Most educated } \\
\text { member: Tertiary }\end{array}$ & 8.42 & - & 5.07 & - & 7.18 & - & 5.49 & - & 5.95 & - \\
\hline
\end{tabular}

Source Author calculations from HIES 2009/2010 data. Note a percentages, education is categorized as primary education (Grades 1-5), junior secondary (Grades 6-9), GCE O/L (Grades 10 and 11), GCE A/L (Grades 12 and 13), and tertiary (graduate or postgraduate). The estate sector is subsumed under rural sector

A clear difference in consumption expenditure between urban and rural sectors as well as between the WP and the rest of Sri Lanka (OP) is indicated by the mean calculations of consumption expenditure per capita as shown in Tables 9.2 
Table 9.3 Descriptive statistics, 2006/2007

\begin{tabular}{|c|c|c|c|c|c|c|c|c|c|c|}
\hline \multicolumn{11}{|l|}{$2006 / 2007$} \\
\hline & \multicolumn{2}{|l|}{ Urban } & \multicolumn{2}{|l|}{ Rural } & \multicolumn{2}{|c|}{ Western Pro. } & \multicolumn{2}{|c|}{ Other Pro. } & \multicolumn{2}{|c|}{ National } \\
\hline & Mean & St. De. & Mean & St. De. & Mean & St. De. & Mean & St. De. & Mean & St. De. \\
\hline $\begin{array}{l}\text { Real expenditure } \\
\text { per capita }\end{array}$ & 6,226 & 5,368 & 4,438 & 4,621 & 5,978 & 6,217 & 4,465 & 4,186 & 4,885 & 4,883 \\
\hline $\begin{array}{l}\text { Engaged in } \\
\text { agricultural work }^{\mathrm{a}}\end{array}$ & 8.89 & - & 36.61 & - & 13.05 & - & 35.76 & - & 29.46 & - \\
\hline $\begin{array}{l}\text { Number of } \\
\text { employed in the } \\
\text { family }\end{array}$ & 1.42 & 0.94 & 1.49 & 0.91 & 1.53 & 0.95 & 1.45 & 0.91 & 1.47 & 0.92 \\
\hline Head's age & 50.28 & 13.71 & 50.54 & 13.91 & 50.97 & 13.80 & 50.29 & 13.87 & 50.47 & 13.86 \\
\hline $\begin{array}{l}\text { Male household } \\
\text { head }^{\text {a }}\end{array}$ & 74.27 & - & 76.82 & - & 77.15 & - & 75.82 & - & 76.18 & - \\
\hline $\begin{array}{l}\text { Head's race: } \\
\text { Sinhala }{ }^{a}\end{array}$ & 63.26 & - & 78.94 & - & 82.34 & - & 72.22 & - & 75.03 & - \\
\hline $\begin{array}{l}\text { Head's race: } \\
\text { Tamil }^{\text {a }}\end{array}$ & 15.50 & - & 15.23 & - & 9.25 & - & 17.62 & - & 15.30 & - \\
\hline $\begin{array}{l}\text { Head's race: } \\
\text { Muslim or other }\end{array}$ & 21.24 & - & 5.82 & - & 4.41 & - & 10.16 & - & 9.67 & - \\
\hline Household size & 4.38 & 1.89 & 4.06 & 1.64 & 4.23 & 1.71 & 4.10 & 1.71 & 4.18 & 1.71 \\
\hline $\begin{array}{l}\text { Number of } \\
\text { dependents in the } \\
\text { family }\end{array}$ & 1.41 & 1.22 & 1.33 & 1.17 & 1.32 & 1.61 & 1.36 & 1.19 & 1.35 & 1.18 \\
\hline $\begin{array}{l}\text { Most educated } \\
\text { member: no } \\
\text { schooling/ } \\
\text { primary }^{\mathrm{a}}\end{array}$ & 4.10 & - & 9.32 & - & 4.18 & - & 9.49 & - & 8.01 & - \\
\hline $\begin{array}{l}\text { Most educated } \\
\text { member: junior } \\
\text { secondary }^{\mathrm{a}}\end{array}$ & 14.16 & - & 18.83 & - & 13.99 & - & 19.08 & - & 17.67 & - \\
\hline $\begin{array}{l}\text { Most educated } \\
\text { member: GCE } \\
\mathrm{O} / \mathrm{L}^{\mathrm{a}}\end{array}$ & 38.16 & - & 40.33 & - & 41.04 & - & 39.31 & - & 39.79 & - \\
\hline $\begin{array}{l}\text { Most educated } \\
\text { member: GCE } \\
\mathrm{A} / \mathrm{L}^{\mathrm{a}}\end{array}$ & 35.36 & - & 27.14 & - & 34.01 & - & 27.34 & - & 29.19 & - \\
\hline $\begin{array}{l}\text { Most educated } \\
\text { member: tertiary }\end{array}$ & 8.22 & - & 4.38 & - & 6.78 & - & 4.78 & - & 5.34 & - \\
\hline
\end{tabular}

Source Author calculations from HIES 2006/2007 data. Note a percentages, education is categorized as primary education (Grades 1-5), junior secondary (Grades 6-9), GCE O/L (Grades 10 and 11), GCE A/L (Grades 12 and 13), and tertiary (graduate or postgraduate). The estate sector is subsumed under rural sector

and 9.3. Rural consumption was around $70 \%$ of the urban consumption in both the survey years. Figure 9.1 illustrates the difference in log real expenditure per capita (LREPC) distributions with kernel density curves for urban, rural, Western, and other provinces for 2006/2007 and 2009/2010. Urban and WP consumption densities lie to the right of the rural and other province densities (respectively), 

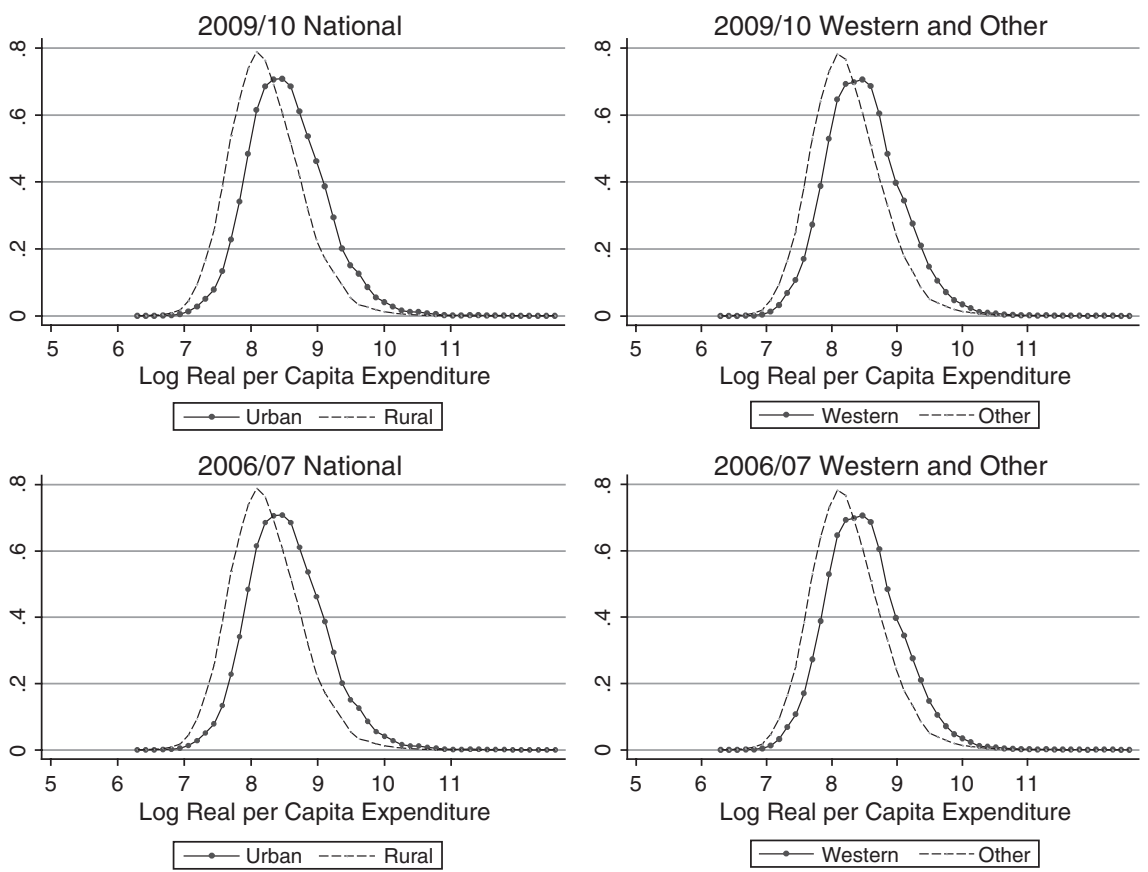

Fig. 9.1 Kernel density curves

indicating higher consumption for urban and WP populations throughout the distribution. The urban-rural consumption gap is greater in 2006/2007 relative to $2009 / 2010$, suggesting that recent regional development programs of the country are delivering the expected results. The consumption expenditure gap is wider in the upper consumption percentiles. This result is comparable to that found in Viet Nam using a similar analysis (Nguyen et al. 2006).

Descriptive statistics (Tables 9.2 and 9.3) give an indication of the differences in endowments between urban and rural areas and the WP and other provinces. Urban areas and the WP have more educated households, greater ethnic diversity, as is to be expected, and a much smaller proportion of households employed in agricultural work.

Table 9.3 indicates that educational endowments beyond junior secondary level have increased in the population as a whole between 2006/2007 and 2009/2010.

The percentage of those employed in the agricultural sector in rural and urban areas continued to decline over the period, while changes (decline) in the number of dependents and household size were marginal. The age and gender of household heads did not change significantly over the period. 


\subsection{Discussion of Results and Conclusions}

In this section, we first present the OLS and quantile regression results on which the decompositions are based. We then present the results of decomposing the consumption gap between urban and rural Sri Lanka, and between the WP and other provinces in two segments: the consumption gap (difference) due to the differences in household endowments (characteristics) and the difference due to location (area of residence). ${ }^{8}$ These decompositions are derived by applying the methodology described in Sect. 9.2.

\subsubsection{Regression Results}

A detailed discussion of OLS and quantile regression estimates on which the decompositions were based is presented in Kumara $(2009,2012) .{ }^{9}$ A brief summary is given here (and in table form in appendix Tables 9.5, 9.6, 9.7, and 9.8). OLS and QR estimates suggest that household consumption increases monotonically with the level of education. An additional finding of the $\mathrm{QR}$ analysis is that the impact of education on consumption is significantly higher in the upper consumption quantiles for all education levels but the junior secondary level. Impact of education on consumption expenditure is relatively high for the lower consumption groups.

An additional employed member in the family increases the household consumption level to a greater extent in the urban sector (WP) than in the rural (OP) sector, while engagement in agricultural work reduces household consumption irrespective of the area of living. This is consistent with previous findings (World Bank 2004, 2005b). ${ }^{10}$ A male-headed household consumes more compared to a femaleheaded household, and the result is stronger in the urban sector and in the WP.

The negative relationship between the number of household members engaged in agricultural work and household consumption persists in the QR analysis, and the impact is higher in the upper expenditure quantiles. QR analysis indicates that additional employment in the family generates more positive impacts on consumption in the upper expenditure quantiles, whereas the effect is weaker in the lower quantiles. Agricultural employment reduces consumption of upper quantile

\footnotetext{
8 The latter component could include the effect of any variable not included among the regressors correlated with location.

9 These can be obtained from the author on request.

10 The incidence of poverty in the households working in agriculture, forestry, and fishing industries is about $40 \%$.
} 
households more than the lower quantiles irrespective of the area of living. This finding holds for both the survey years.

The consumption advantage of male-headed households becomes weaker in the upper expenditure quantiles and in the urban sector in both the periods. ${ }^{11}$ This suggests that the gender of the household head is irrelevant for the upper consumption groups and for the urban sector. Most formal jobs that pay equal wages for both males and females are concentrated in urban areas, whereas most informal jobs that discriminate against females are concentrated in rural areas. This may explain the equal benefits in urban areas and the differences in rural areas. An additional member in the household generates negative results for all the quantiles, and the impact is significantly higher in upper expenditure groups and urban areas.

As suggested by the OLS estimation, Muslim and other ethnic groups have a higher consumption expenditure compared to their Sinhala counterparts in all the consumption quantiles. Furthermore, the percentage increase is higher in the upper consumption groups. Analogous to the OLS results, QR estimates also show that there is a negative correlation between the household consumption expenditure and households headed by persons of Tamil ethnic origin, as compared to households headed by Sinhala counterparts.

\subsubsection{Inequality Decomposition}

In this section, mean regression (Oaxaca 1973; Blinder 1973) and quantile regression (Machado and Mata 2005) methods are applied in decomposing consumption inequalities in Sri Lanka into two components: (1) a component that is due to the differences in the distribution of household endowments (covariate effect) between urban and rural sectors in Sri Lanka and (2) another component that is due to the location-specific returns (returns effect) to these covariates.

The mean regression decomposition method considers the means of two distributions. Adding value to the analysis, quantile regression decomposes the gap according to the differences at each quantile. In decomposing urban-rural (Western-other province) inequality, it compares rural household LREPC with a simulated (counterfactual) LREPC derived from rural characteristics (endowments) and urban (coefficients) returns. This estimates the difference in consumption between an urban household and a rural household that are identically endowed, where the only difference between them is the location. In other words, if the level of average urban (WP) household endowments was suddenly replaced by the level of endowments of average rural (other provinces) households, how large would the spatial consumption gap (i.e., the returns effect) be? If rural (OP) households were to move instantaneously (and without cost) to urban (WP) areas, what would the consumption gap between them and identical households in rural

11 This relationship holds for most of the rural households and lower consumption groups. 
Table 9.4 Total gap and unexplained gap (returns effect) 2009/2010 and 2006/2007

\begin{tabular}{|c|c|c|c|c|c|c|}
\hline & \multicolumn{6}{|c|}{ Percentile } \\
\hline & \multirow[t]{2}{*}{ Mean } & \multirow[t]{2}{*}{5 th } & 25 th & \multirow[t]{2}{*}{50 th } & \multirow[t]{2}{*}{75 th } & \multirow[t]{2}{*}{95 th } \\
\hline & & & $2009 / 2010$ & & & \\
\hline \multicolumn{7}{|l|}{ Total gap } \\
\hline Urban-rural & $\begin{array}{l}0.320 \\
(0.009)\end{array}$ & $\begin{array}{l}0.285 \\
(0.016)\end{array}$ & $\begin{array}{l}0.294 \\
(0.005)\end{array}$ & $\begin{array}{l}0.316 \\
(0.011)\end{array}$ & $\begin{array}{l}0.346 \\
(0.013)\end{array}$ & $\begin{array}{l}0.383 \\
(0.025)\end{array}$ \\
\hline Western and other & $\begin{array}{l}0.266 \\
(0.009)\end{array}$ & $\begin{array}{l}0.229 \\
(0.016)\end{array}$ & $\begin{array}{l}0.238 \\
(0.011)\end{array}$ & $\begin{array}{l}0.270 \\
(0.010)\end{array}$ & $\begin{array}{l}0.279 \\
(0.013)\end{array}$ & $\begin{array}{l}0.317 \\
(0.022)\end{array}$ \\
\hline \multicolumn{7}{|l|}{ Returns effect } \\
\hline Urban-rural & $\begin{array}{l}0.243 \\
(0.008)\end{array}$ & $\begin{array}{l}0.237 \\
(0.021)\end{array}$ & $\begin{array}{l}0.240 \\
(0.014)\end{array}$ & $\begin{array}{l}0.238 \\
(0.015)\end{array}$ & $\begin{array}{l}0.248 \\
(0.017)\end{array}$ & $\begin{array}{l}0.265 \\
(0.022)\end{array}$ \\
\hline Western and other & $\begin{array}{l}0.193 \\
(0.008)\end{array}$ & $\begin{array}{l}0.176 \\
(0.018)\end{array}$ & $\begin{array}{l}0.187 \\
(0.014)\end{array}$ & $\begin{array}{l}0.189 \\
(0.013)\end{array}$ & $\begin{array}{l}0.202 \\
(0.015)\end{array}$ & $\begin{array}{l}0.216 \\
(0.030)\end{array}$ \\
\hline \multicolumn{7}{|c|}{ Returns effect as a percentage of total gap } \\
\hline Urban-rural & 75.94 & 83.16 & 81.63 & 75.32 & 71.68 & 69.19 \\
\hline \multirow[t]{2}{*}{ Western and other } & 72.56 & 76.86 & 78.57 & 70.00 & 72.40 & 68.14 \\
\hline & & & $2006 / 2007$ & & & \\
\hline \multicolumn{7}{|l|}{ Total gap } \\
\hline Urban-rural & $\begin{array}{l}0.330 \\
(0.010)\end{array}$ & $\begin{array}{l}0.267 \\
(0.017)\end{array}$ & $\begin{array}{l}0.302 \\
(0.012)\end{array}$ & $\begin{array}{l}0.336 \\
(0.010)\end{array}$ & $\begin{array}{l}0.375 \\
(0.014)\end{array}$ & $\begin{array}{l}0.385 \\
(0.027)\end{array}$ \\
\hline Western and other & $\begin{array}{l}0.275 \\
(0.010)\end{array}$ & $\begin{array}{l}0.259 \\
(0.012)\end{array}$ & $\begin{array}{l}0.269 \\
(0.012)\end{array}$ & $\begin{array}{l}0.282 \\
(0.012)\end{array}$ & $\begin{array}{l}0.276 \\
(0.015)\end{array}$ & $\begin{array}{l}0.288 \\
(0.025)\end{array}$ \\
\hline \multicolumn{7}{|l|}{ Returns effect } \\
\hline Urban-rural & \begin{tabular}{|l|}
0.256 \\
$(0.009)$ \\
\end{tabular} & $\begin{array}{l}0.239 \\
(0.021)\end{array}$ & $\begin{array}{l}0.251 \\
(0.013)\end{array}$ & $\begin{array}{l}0.256 \\
(0.014) \\
\end{array}$ & \begin{tabular}{|l|}
0.271 \\
$(0.015)$ \\
\end{tabular} & \begin{tabular}{|l|l}
0.266 \\
$(0.026)$ \\
\end{tabular} \\
\hline Western and other & $\begin{array}{l}0.196 \\
(0.009)\end{array}$ & $\begin{array}{l}0.198 \\
(0.020)\end{array}$ & $\begin{array}{l}0.197 \\
(0.014)\end{array}$ & $\begin{array}{l}0.195 \\
(0.012)\end{array}$ & $\begin{array}{l}0.205 \\
(0.015)\end{array}$ & $\begin{array}{l}0.203 \\
(0.023)\end{array}$ \\
\hline \multicolumn{7}{|c|}{ Returns effect as a percentage of total gap } \\
\hline Urban-rural & 77.58 & 89.51 & 83.11 & 76.19 & 72.27 & 69.09 \\
\hline Western and other & 71.27 & 76.45 & 73.23 & 69.15 & 74.28 & 70.49 \\
\hline \multicolumn{7}{|c|}{$\%$ Change 2009/2010-2006/2007 } \\
\hline Urban-rural & -2.11 & -7.10 & -1.78 & -1.15 & -0.82 & 0.14 \\
\hline Western and other & 1.80 & 0.53 & 7.29 & 1.23 & -2.52 & -3.33 \\
\hline
\end{tabular}

Source Author's calculations using HIES 2009/2010 and 2006/2007. Standard errors are in parentheses and all the coefficients are significant at $1 \%$ level

(OP) areas be? This component captures location-specific effects on consumption. With markets working perfectly, and no barriers to mobility (and a well-specified model), this gap would in the long term be zero. The entirety of the consumption gap would then be due to differences in characteristics between urban and rural (Western and other) households, captured by the covariates effect.

Both mean regression and quantile regression decomposition results are presented in Table 9.4 and Fig. 9.2. The second column of the table represents the decomposition results based on the mean regression analysis, and the 3rd to 7th columns represent the 5th, 25th, 50th, 75th, and 95th quantiles of the quantile 

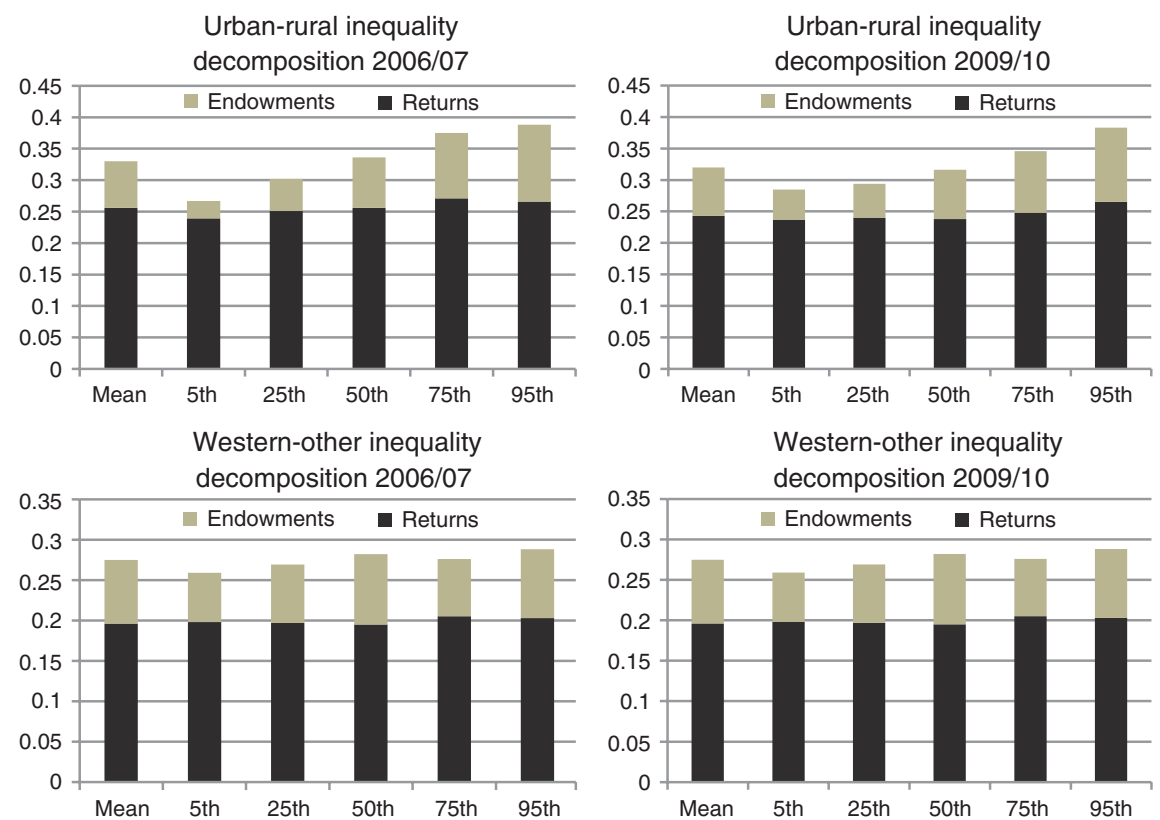

Fig. 9.2 Inequality decomposition: returns effect and endowment effect

regression analysis. The first panel illustrates the total consumption gap between the urban and rural sectors in Sri Lanka, and the second panel shows the decomposition results.

Mean regression analysis suggests that consumption inequality in Sri Lanka slightly decreased during the study period (second column in Table 9.4). This may be due to the recent regional development projects carried in Sri Lanka, discussed in Sect. 9.1. ${ }^{12}$

The urban-rural and WP-OP gaps that remain after controlling for household characteristics (evaluating urban consumption using rural household endowments) are positive. This signifies that even after adjusting urban consumption for rural endowment (characteristics), urban consumption is higher than rural consumption. This component is defined as the location-specific returns to household endowments. The major portion of the mean urban-rural consumption gap in Sri Lanka is explained by the returns effect, and its dominance is the same in both the surveys.

\footnotetext{
12 A new sea port, an airport, a film village, and a cricket ground in Hambantota; a new expressway between Galle and Colombo; Maga Neguma (Road improvement) and Divi Neguma (life improvement) in rural provinces; and special development projects for the war-affected North and Eastern Provinces are some of the regional development programs carried out recently.
} 
The dominance of the returns effect is observed in the quantile regression decomposition for all quantiles. For any quantile, for both survey years, the urbanrural (WO) consumption gap was recorded as positive, implying that the urbanrural (WO) gap favors the urban sector (WP) even after evaluating urban (WP) consumption with rural (OP) characteristics. This suggests that even though the consumption inequalities declined between the two survey years in Sri Lanka, the returns effect is still dominant.

Three major policy conclusions can be drawn from the quantile regression decomposition analysis. First, the urban-rural (total or unadjusted) consumption gap is smaller in the lower consumption quantiles and significantly higher in the upper quantiles. The difference in consumption expenditure gaps between the 95th percentile and 5th percentile is around $30 \%$ in both the survey periods. This implies that the urban (WP) rich are much better off than the rural (other province) rich in terms of consumption expenditure. Second, the returns effect dominates throughout the distribution of consumption expenditure. The unexplained percentage of consumption gap is always more than $70 \%$ of the total gap for all quantiles. Third, adding to the second conclusion, the returns effect dominates throughout the expenditure distribution, but tends to decline as it moves toward the upper consumption quantiles. This means that location-specific effects account for more than $80 \%$ of the urban-rural total gap at the 5th quantile compared to less than $70 \%$ of the urban-rural total gap in the 95th quantile. On the other hand, the importance of the covariate effect in explaining the urban-rural gap increases at the upper end of the expenditure quantiles. These findings are different from those of Nguyen et al. (2006) using the same analytical method for Viet Nam. They found that the covariate effect dominates in the lower quantiles, whereas the returns effect dominates in the upper quantiles.

A temporal analysis of the urban-rural inequality decomposition based on quantile regression analysis also finds that urban-rural inequality decreased over the study period, and inequality between the lower end and the upper end of the consumption distribution reduced relatively in 2009/2010. Furthermore, the dominance of the returns effect also declined in urban-rural analysis, while there was not much change in the WP and other process analysis.

The dominance of the returns effect in the lower quantiles of the consumption expenditure distribution suggests that returns to household endowments matter more than household characteristics to poor people in Sri Lanka. Sri Lanka is recognized as a country that has achieved extraordinary success in health and education indicators despite a lower level of income per capita (World Bank 2005b). Sri Lanka also records a relatively high rank in the UNDP 'Human Development Index.' Gender seems to matter less in determining household characteristics (e.g., education and health) in Sri Lanka compared to many other developing countries. This suggests that the distribution of household characteristics is relatively better in Sri Lanka as compared to Viet Nam. The lower rewards to rural households can be linked to the poor rural markets. Most formal employment is concentrated in urban areas, and rural areas are separated from the urban centers due to the poor road network, leading to poorer market access for the rural population. 
The communication barriers between urban (WP) and rural (OP) areas may also contribute to lower rewards to the characteristics in the rural sector. In addition, if characteristics for which controls were not included due to lack of data, such as the quality of education, are correlated with location (for instance, richer areas have better quality education), then these would add to the location-specific effects.

The foregoing analysis suggests that the existence of barriers such as remoteness and poor access to markets prevents lagging regions from being absorbed into the modern sector or growing region. These barriers play a larger role in perpetuating spatial inequality, especially for the poor, than do disparities in household endowments between regions and sectors.

Policies that are indicated for further reduction in the urban-rural gap and higher poverty levels in the rural areas include (1) connecting lagging regions to markets in the growing regions, i.e., improvement of roads and transportation, electricity and communication infrastructure, and improving the investment climate in the rural areas; (2) improving the quality of schooling via better training and resources, especially in remote areas; and (3) removing barriers to labor mobility such as regulations in labor markets and land markets.

\section{Appendix}

See Tables 9.5, 9.6, 9.7, and 9.8

Table 9.5 OLS estimates 2009/2010

\begin{tabular}{l|l|l|l|l|l}
\hline \multirow{2}{*}{ Variable } & \multicolumn{5}{l}{ Coefficient } \\
\cline { 2 - 6 } & National & Urban & Rural & Western & Other \\
\hline Constant & $8.572 * * *$ & $8.734 * * *$ & $8.627 * * *$ & $8.761 * * *$ & $8.436 * * *$ \\
& 0.021 & 0.050 & 0.025 & 0.050 & 0.024 \\
\hline Agricultural & $-0.083 * * *$ & $0.108 * * *$ & $-0.040 * * *$ & $-0.082 * * *$ & $-0.073 * * *$ \\
employment & 0.008 & 0.024 & 0.008 & 0.020 & 0.008 \\
\hline Number of employed & $0.025 * * *$ & $0.119 * * *$ & $0.061 * * *$ & $0.167 * * *$ & $0.070 * * *$ \\
& 0.005 & 0.024 & 0.014 & 0.026 & 0.014 \\
\hline Head's age & $0.001 * * *$ & $0.002 * * *$ & 0.000 & 0.000 & $0.001 * * *$ \\
& 0.000 & 0.001 & 0.000 & 0.001 & 0.000 \\
\hline Male head & $0.046 * * *$ & $0.075 * * *$ & $0.061 * * *$ & $0.069 * * *$ & $0.057 * * *$ \\
& 0.008 & 0.016 & 0.009 & 0.016 & 0.010 \\
\hline Household size & $-0.148 * * *$ & $-0.129 * * *$ & $-0.137 * * *$ & $-0.124 * * *$ & $-0.137 * * *$ \\
& 0.003 & 0.005 & 0.003 & 0.005 & 0.003
\end{tabular}


Table 9.5 (continued)

\begin{tabular}{|c|c|c|c|c|c|}
\hline \multirow[t]{2}{*}{ Variable } & \multicolumn{5}{|l|}{ Coefficient } \\
\hline & National & Urban & Rural & Western & Other \\
\hline $\begin{array}{l}\text { Number of } \\
\text { dependants }\end{array}$ & $\begin{array}{l}0.007 * \\
0.004\end{array}$ & $\begin{array}{l}-0.001 \\
0.007\end{array}$ & $\begin{array}{l}-0.007 * \\
0.004\end{array}$ & $\begin{array}{l}-0.014 * * \\
0.007\end{array}$ & $\begin{array}{l}-0.001 \\
0.004\end{array}$ \\
\hline Race: Tamil & $\begin{array}{l}-0.090 * * * \\
0.010\end{array}$ & $\begin{array}{l}-0.138 * * * \\
0.020\end{array}$ & $\begin{array}{l}-0.085^{* * * *} \\
0.011\end{array}$ & $\begin{array}{l}-0.075 * * * \\
0.023\end{array}$ & $\begin{array}{l}-0.058 * * * \\
0.011\end{array}$ \\
\hline Race: Muslim/other & $\begin{array}{l}0.117 * * * \\
0.012\end{array}$ & $\begin{array}{l}-0.013 \\
0.018 \\
\end{array}$ & $\begin{array}{l}0.100 * * * \\
0.016\end{array}$ & $\begin{array}{l}0.135 * * * \\
0.025\end{array}$ & $\begin{array}{l}0.174 * * * \\
0.013\end{array}$ \\
\hline $\begin{array}{l}\text { Education: Jun. } \\
\text { Secondary }\end{array}$ & $\begin{array}{l}0.170 * * * \\
0.013\end{array}$ & $\begin{array}{l}0.148 * * * \\
0.036\end{array}$ & $\begin{array}{l}0.155^{* * * *} \\
0.014\end{array}$ & $\begin{array}{l}0.167 * * * \\
0.035\end{array}$ & $\begin{array}{l}0.183 * * * \\
0.015\end{array}$ \\
\hline Education: GCE O/L & $\begin{array}{l}0.412 * * * \\
0.015\end{array}$ & $\begin{array}{l}0.352 * * * \\
0.038\end{array}$ & $\begin{array}{l}0.380 * * * \\
0.017\end{array}$ & $\begin{array}{l}0.373 * * * \\
0.037\end{array}$ & $\begin{array}{l}0.445 * * * \\
0.017\end{array}$ \\
\hline Education: GCE A/L & $\begin{array}{l}0.598 * * * \\
0.014\end{array}$ & $\begin{array}{l}0.544 * * * \\
0.037\end{array}$ & $\begin{array}{l}0.553 * * * \\
0.016\end{array}$ & $\begin{array}{l}0.594 * * * \\
0.036\end{array}$ & $\begin{array}{l}0.618 * * * \\
0.016\end{array}$ \\
\hline Education: Tertiary & $\begin{array}{l}0.935^{* * * *} \\
0.019\end{array}$ & $\begin{array}{l}0.908 * * * \\
0.042\end{array}$ & $\begin{array}{l}0.850 * * * \\
0.022\end{array}$ & $\begin{array}{l}0.965 * * * \\
0.042\end{array}$ & $\begin{array}{l}0.954 * * * \\
0.022\end{array}$ \\
\hline $\begin{array}{l}\text { Prov: Central } \\
\text { Province }\end{array}$ & $\begin{array}{l}-0.182 * * * \\
0.011\end{array}$ & $\begin{array}{l}-0.048 * * \\
0.024\end{array}$ & $\begin{array}{l}-0.194 * * * \\
0.012\end{array}$ & - & - \\
\hline $\begin{array}{l}\text { Prov: Southern } \\
\text { Province }\end{array}$ & $\begin{array}{l}-0.090 * * * \\
0.010\end{array}$ & $\begin{array}{l}-0.100 * * * \\
0.018\end{array}$ & $\begin{array}{l}-0.088 * * * \\
0.011\end{array}$ & - & - \\
\hline $\begin{array}{l}\text { Prov: North Western } \\
\text { Province }\end{array}$ & $\begin{array}{l}-0.173 * * * \\
0.012\end{array}$ & $\begin{array}{l}-0.044 \\
0.030\end{array}$ & $\begin{array}{l}-0.169 * * * \\
0.013\end{array}$ & - & - \\
\hline Prov: North Central & $\begin{array}{l}-0.184 * * * \\
0.014\end{array}$ & $\begin{array}{l}0.013 \\
0.041\end{array}$ & $\begin{array}{l}-0.187 * * * \\
0.015\end{array}$ & - & - \\
\hline Prov: Uva Province & $\begin{array}{l}-0.293 * * * \\
0.014\end{array}$ & $\begin{array}{l}-0.039 \\
0.044\end{array}$ & $\begin{array}{l}-0.296 * * * \\
0.015\end{array}$ & - & - \\
\hline Provi: Sabaragamuwa & $\begin{array}{l}-0.293 * * * \\
0.013\end{array}$ & $\begin{array}{l}-0.259 * * * \\
0.036\end{array}$ & $\begin{array}{l}-0.264 * * * \\
0.013\end{array}$ & - & - \\
\hline F Value & 625.02 & 150.31 & 457.70 & 211.76 & 587.09 \\
\hline Prob. F. & 0.00 & 0.00 & 0.00 & 0.00 & 0.00 \\
\hline R Squared & 0.37 & 0.36 & 0.37 & 0.33 & 0.34 \\
\hline Adj. R Squared & 0.37 & 0.36 & 0.37 & 0.32 & 0.34 \\
\hline
\end{tabular}

Source Author's calculations using HIES 2009/2010, education is categorized as primary education (Grades 1-5), junior secondary (Grades 6-9), GCE O/L (Grades 10 and 11), GCE A/L (Grades 12 and 13), and tertiary (graduate or postgraduate). Standard errors are in parentheses; $*$, ** and $* * *$ indicate significance at 10,5 and $1 \%$ levels, respectively 
Table 9.6 OLS estimates 2006/2007

\begin{tabular}{|c|c|c|c|c|c|}
\hline \multirow[t]{2}{*}{ Variable } & \multicolumn{5}{|l|}{ Coefficient } \\
\hline & National & Urban & Rural & Western & Other \\
\hline Constant & $\begin{array}{l}8.575 * * * \\
(0.022)\end{array}$ & $\begin{array}{l}8.646 * * * \\
(0.051)\end{array}$ & $\begin{array}{l}8.579 * * * \\
(0.023)\end{array}$ & $\begin{array}{l}8.619 * * * \\
(0.043)\end{array}$ & $\begin{array}{l}8.381 * * * \\
(0.024)\end{array}$ \\
\hline Agricultural employment & $\begin{array}{l}-0.073 * * * \\
(0.008)\end{array}$ & $\begin{array}{l}-0.097 * * * \\
(0.026)\end{array}$ & $\begin{array}{l}-0.038 * * * \\
(0.008)\end{array}$ & $\begin{array}{l}-0.103 * * * \\
(0.020)\end{array}$ & $\begin{array}{l}-0.081 * * * \\
(0.009)\end{array}$ \\
\hline Number of employed & $\begin{array}{l}0.017 * * * \\
(0.005)\end{array}$ & $\begin{array}{l}0.024 * * \\
(0.009)\end{array}$ & $\begin{array}{l}0.021 * * * \\
(0.005)\end{array}$ & $\begin{array}{l}0.006 \\
(0.008)\end{array}$ & $\begin{array}{l}0.022 * * * \\
(0.006)\end{array}$ \\
\hline Head's age & $\begin{array}{l}0.001 * * * \\
(0.000)\end{array}$ & $\begin{array}{l}0.002 * * * \\
(0.000)\end{array}$ & $\begin{array}{l}0.000 \\
(0.000)\end{array}$ & $\begin{array}{l}0.000 \\
(0.000)\end{array}$ & $\begin{array}{l}0.001 * * * \\
(0.000)\end{array}$ \\
\hline Male head & $\begin{array}{l}0.043 * * * \\
(0.008)\end{array}$ & $\begin{array}{l}0.042 * * * \\
(0.017)\end{array}$ & $\begin{array}{l}0.061 * * * \\
(0.009)\end{array}$ & $\begin{array}{l}0.037 * * * \\
(0.015)\end{array}$ & $\begin{array}{l}0.050 * * * \\
(0.037)\end{array}$ \\
\hline Household size & $\begin{array}{l}-0.147 * * * \\
(0.003)\end{array}$ & $\begin{array}{l}-0.151 * * * \\
(0.006)\end{array}$ & $\begin{array}{l}-0.150 * * * \\
(0.004)\end{array}$ & $\begin{array}{l}-0.140 * * * \\
(0.006)\end{array}$ & $\begin{array}{l}-0.150 * * * \\
(0.004)\end{array}$ \\
\hline Number of dependants & $\begin{array}{l}0.005 \\
(0.004)\end{array}$ & $\begin{array}{l}0.013 \\
(0.008)\end{array}$ & $\begin{array}{l}0.004 \\
(0.005)\end{array}$ & $\begin{array}{l}0.000 \\
(0.007)\end{array}$ & $\begin{array}{l}0.008 \\
(0.005)\end{array}$ \\
\hline Race: Tamil & $\begin{array}{l}-0.055^{* * * *} \\
(0.012)\end{array}$ & $\begin{array}{l}-0.041^{*} \\
(0.024)\end{array}$ & $\begin{array}{l}-0.066^{* * * *} \\
(0.012)\end{array}$ & $\begin{array}{l}-0.080 * * * \\
(0.002)\end{array}$ & $\begin{array}{l}-0.097 * * * \\
(0.013)\end{array}$ \\
\hline Race: Muslim/other & $\begin{array}{l}0.162 * * * \\
(0.013)\end{array}$ & $\begin{array}{l}0.057 * * * \\
(0.020)\end{array}$ & $\begin{array}{l}0.138 * * * \\
(0.019)\end{array}$ & $\begin{array}{l}0.137 * * * \\
(0.023)\end{array}$ & $\begin{array}{l}0.175 * * * \\
(0.017)\end{array}$ \\
\hline $\begin{array}{l}\text { Education: Jun. } \\
\text { secondary }\end{array}$ & $\begin{array}{l}0.176^{* * * *} \\
(0.014)\end{array}$ & $\begin{array}{l}0.133 * * * \\
(0.040)\end{array}$ & $\begin{array}{l}0.159 * * * \\
(0.014)\end{array}$ & $\begin{array}{l}0.167 * * * \\
(0.033)\end{array}$ & $\begin{array}{l}0.180 * * * \\
(0.016)\end{array}$ \\
\hline Education: GCE O/L & $\begin{array}{l}0.423 * * * \\
(0.016)\end{array}$ & $\begin{array}{l}0.353 * * * \\
(0.042)\end{array}$ & $\begin{array}{l}0.394 * * * \\
(0.017)\end{array}$ & $\begin{array}{l}0.383 * * * \\
(0.035)\end{array}$ & $\begin{array}{l}0.451 * * * \\
(0.019)\end{array}$ \\
\hline Education: GCE A/L & $\begin{array}{l}0.605 * * * \\
(0.015)\end{array}$ & $\begin{array}{l}0.544 * * * \\
(0.041)\end{array}$ & $\begin{array}{l}0.551 * * * \\
(0.016)\end{array}$ & $\begin{array}{l}0.585 * * * \\
(0.034)\end{array}$ & $\begin{array}{l}0.620 * * * \\
(0.017)\end{array}$ \\
\hline Education: Tertiary & $\begin{array}{l}0.931 * * * \\
(0.020)\end{array}$ & $\begin{array}{l}0.871 * * * \\
(0.046)\end{array}$ & $\begin{array}{l}0.847 * * * \\
(0.022)\end{array}$ & $\begin{array}{l}0.902 * * * \\
(0.040)\end{array}$ & $\begin{array}{l}0.954 * * * \\
(0.024)\end{array}$ \\
\hline Province: Central & $\begin{array}{l}-0.189 * * * \\
(0.011)\end{array}$ & $\begin{array}{l}-0.065 * * * \\
(0.045) 0)\end{array}$ & $\begin{array}{l}-0.192 * * * \\
(0.012)\end{array}$ & - & - \\
\hline Province: Southern & $\begin{array}{l}-0.097 * * * \\
(0.010)\end{array}$ & $\begin{array}{l}-0.104 * * * \\
(0.018)\end{array}$ & $\begin{array}{l}-0.092 * * * \\
(0.011)\end{array}$ & - & - \\
\hline Province: North Western & $\begin{array}{l}-0.152 * * * \\
(0.012)\end{array}$ & $\begin{array}{l}-0.058 * \\
(0.030)\end{array}$ & $\begin{array}{l}-0.140 * * * \\
(0.013)\end{array}$ & - & - \\
\hline Province: North Central & $\begin{array}{l}-0.155^{* * * *} \\
(0.014)\end{array}$ & $\begin{array}{l}-0.039 \\
(0.041)\end{array}$ & $\begin{array}{l}-0.155^{* * * *} \\
(0.015)\end{array}$ & - & - \\
\hline Province: Uva & $\begin{array}{l}-0.288 * * * \\
(0.014)\end{array}$ & $\begin{array}{l}-0.026 \\
(0.043)\end{array}$ & $\begin{array}{l}-0.284 * * * \\
(0.015)\end{array}$ & - & - \\
\hline Province: Sabaragamuwa & $\begin{array}{l}-0.312 * * * \\
(0.013)\end{array}$ & $\begin{array}{l}-0.289 * * * \\
(0.036)\end{array}$ & $\begin{array}{l}-0.279 * * * \\
(0.014)\end{array}$ & - & - \\
\hline F Value & 589.12 & 134.20 & 436.04 & 212.53 & 536.05 \\
\hline Prob. F. & 0.00 & 0.00 & 0.00 & 0.00 & 0.00 \\
\hline R Squared & 0.38 & 0.38 & 0.38 & 0.33 & 0.35 \\
\hline Adj. R Squared & 0.38 & 0.37 & 0.37 & 0.33 & 0.35 \\
\hline
\end{tabular}

Source Author's calculations using HIES 2006/2007, education is categorized as primary education (Grades 1-5), junior secondary (Grades 6-9), GCE O/L (Grades 10 and 11), GCE A/L (Grades 12 and 13), and tertiary (graduate or postgraduate). Standard errors are in parentheses; $*, * *$ and $* * *$ indicate significance at 10,5 and $1 \%$ levels, respectively 
Table 9.7 QR estimates 2009/2010 national sample

\begin{tabular}{|c|c|c|c|c|c|}
\hline \multirow[t]{2}{*}{ Variable } & \multicolumn{5}{|l|}{ Quantile } \\
\hline & 5 th & 25 th & 50 th & 75 th & 95 th \\
\hline Constant & $\begin{array}{l}7.856 * * * \\
0.038\end{array}$ & $\begin{array}{l}8.302 * * * \\
0.026\end{array}$ & $\begin{array}{l}8.635 * * * \\
0.029\end{array}$ & $\begin{array}{l}8.947 * * * \\
0.030\end{array}$ & $\begin{array}{l}9.416 * * * \\
0.067\end{array}$ \\
\hline $\begin{array}{l}\text { Agricultural } \\
\text { employment }\end{array}$ & $\begin{array}{l}-0.034 * * \\
0.014\end{array}$ & $\begin{array}{l}-0.055^{* * * *} \\
0.009\end{array}$ & $\begin{array}{l}-0.075 * * * \\
0.10\end{array}$ & $\begin{array}{l}-0.085 * * * \\
0.010\end{array}$ & $\begin{array}{l}-0.041 * \\
0.023\end{array}$ \\
\hline Number of employed & $\begin{array}{l}0.014 \\
0.021\end{array}$ & $\begin{array}{l}0.051 * * * \\
0.014\end{array}$ & $\begin{array}{l}0.082 * * * \\
0.016\end{array}$ & $\begin{array}{l}0.117 * * * \\
0.016\end{array}$ & $\begin{array}{l}0.169 * * * \\
0.036\end{array}$ \\
\hline Head's age & $\begin{array}{l}-0.001 \\
0.000\end{array}$ & $\begin{array}{l}0.000 \\
0.000\end{array}$ & $\begin{array}{l}0.001 * * \\
0.000\end{array}$ & $\begin{array}{l}0.001 * * * \\
0.000\end{array}$ & $\begin{array}{l}0.002 * * \\
0.001\end{array}$ \\
\hline Male head & $\begin{array}{l}0.091 * * * \\
0.014\end{array}$ & $\begin{array}{l}0.061^{* * * *} \\
0.009\end{array}$ & $\begin{array}{l}0.060 * * * \\
0.011\end{array}$ & $\begin{array}{l}0.047 * * * \\
0.011\end{array}$ & $\begin{array}{l}0.035 \\
0.024\end{array}$ \\
\hline Household size & $\begin{array}{l}-0.116^{* * * *} \\
0.004\end{array}$ & $\begin{array}{l}-0.126 * * * \\
0.003\end{array}$ & $\begin{array}{l}-0.133 * * * \\
0.003\end{array}$ & $\begin{array}{l}-0.136 * * * \\
0.004\end{array}$ & $\begin{array}{l}-0.125 * * * \\
0.011\end{array}$ \\
\hline Number of dependants & $\begin{array}{l}-0.004 \\
0.006\end{array}$ & $\begin{array}{l}-0.007 \\
0.004\end{array}$ & $\begin{array}{l}-0.004 \\
0.005\end{array}$ & $\begin{array}{l}-0.007 \\
0.005\end{array}$ & $\begin{array}{l}-0.024 * * \\
0.010\end{array}$ \\
\hline Race: Tamil & $\begin{array}{l}-0.019 \\
0.018\end{array}$ & $\begin{array}{l}-0.034 \\
0.012\end{array}$ & $\begin{array}{l}-0.081 * * * \\
0.013\end{array}$ & $\begin{array}{l}-0.128 * * * \\
0.013\end{array}$ & $\begin{array}{l}-0.168 * * * \\
0.029\end{array}$ \\
\hline Race: Muslim/other & $\begin{array}{l}0.164 * * * \\
0.020\end{array}$ & $\begin{array}{l}0.137 * * * \\
0.014\end{array}$ & $\begin{array}{l}0.103 * * * \\
0.015\end{array}$ & $\begin{array}{l}0.061 * * * \\
0.016\end{array}$ & $\begin{array}{l}0.077 * * \\
0.035\end{array}$ \\
\hline $\begin{array}{l}\text { Education: Jun. } \\
\text { secondary }\end{array}$ & $\begin{array}{l}0.199 * * * \\
0.023\end{array}$ & $\begin{array}{l}0.182 * * * \\
0.015\end{array}$ & $\begin{array}{l}0.149 * * * \\
0.017\end{array}$ & $\begin{array}{l}0.152 * * * \\
0.018\end{array}$ & $\begin{array}{l}0.164 * * * \\
0.039\end{array}$ \\
\hline Education: GCE O/L & $\begin{array}{l}0.383 * * * \\
0.027\end{array}$ & $\begin{array}{l}0.395 * * * \\
0.018\end{array}$ & $\begin{array}{l}0.381 * * * \\
0.020\end{array}$ & $\begin{array}{l}0.408 * * * \\
0.021\end{array}$ & $\begin{array}{l}0.440 * * * \\
0.046\end{array}$ \\
\hline Education: GCE A/L & $\begin{array}{l}0.516 * * * \\
0.025\end{array}$ & $\begin{array}{l}0.541 * * * \\
0.016\end{array}$ & $\begin{array}{l}0.573 * * * \\
0.018\end{array}$ & $\begin{array}{l}0.609 * * * \\
0.019\end{array}$ & $\begin{array}{l}0.707 * * * \\
0.043\end{array}$ \\
\hline Education: Tertiary & $\begin{array}{l}0.843 * * * \\
0.013\end{array}$ & $\begin{array}{l}0.863 * * * \\
0.022\end{array}$ & $\begin{array}{l}0.912 * * * \\
0.025\end{array}$ & $\begin{array}{l}0.959 * * * \\
0.026\end{array}$ & $\begin{array}{l}1.088 * * * \\
0.056\end{array}$ \\
\hline Province: Central & $\begin{array}{l}-0.211 * * * \\
0.019\end{array}$ & $\begin{array}{l}-0.192 * * * \\
0.013\end{array}$ & $\begin{array}{l}-0.172 * * * \\
0.014\end{array}$ & $\begin{array}{l}-0.179 * * * \\
0.015\end{array}$ & $\begin{array}{l}-0.214 * * * \\
0.032\end{array}$ \\
\hline Province: Southern & $\begin{array}{l}-0.063^{* * *} \\
0.016\end{array}$ & $\begin{array}{l}-0.078 * * * \\
0.011\end{array}$ & $\begin{array}{l}-0.082 * * * \\
0.012\end{array}$ & $\begin{array}{l}-0.090 * * * \\
0.013\end{array}$ & $\begin{array}{l}-0.146 * * * \\
0.028\end{array}$ \\
\hline $\begin{array}{l}\text { Province: North } \\
\text { Western }\end{array}$ & $\begin{array}{l}-0.179 * * * \\
0.021\end{array}$ & $\begin{array}{l}-0.179 * * * \\
0.014\end{array}$ & $\begin{array}{l}-0.170 * * * \\
0.015\end{array}$ & $\begin{array}{l}-0.153 * * * \\
0.016\end{array}$ & $\begin{array}{l}-0.167 * * * \\
0.035\end{array}$ \\
\hline Province North Central & $\begin{array}{l}-0.193 * * * \\
0.025\end{array}$ & $\begin{array}{l}-0.178 * * * \\
0.016\end{array}$ & $\begin{array}{l}-0.174 * * * \\
0.018\end{array}$ & $\begin{array}{l}-0.191 * * * \\
0.019\end{array}$ & $\begin{array}{l}-0.236 * * * \\
0.042\end{array}$ \\
\hline Province: Uva & $\begin{array}{l}-0.307 * * * \\
0.025\end{array}$ & $\begin{array}{l}-0.306 * * * \\
0.016\end{array}$ & $\begin{array}{l}-0.297 * * * \\
0.018\end{array}$ & $\begin{array}{l}-0.273 * * * \\
0.019\end{array}$ & $\begin{array}{l}-0.334 * * * \\
0.041\end{array}$ \\
\hline $\begin{array}{l}\text { Province: } \\
\text { Sabaragamuwa }\end{array}$ & $\begin{array}{l}-0.250 * * * \\
0.022\end{array}$ & $\begin{array}{l}-0.288 * * * \\
0.015\end{array}$ & $\begin{array}{l}-0.295 * * * \\
0.016\end{array}$ & $\begin{array}{l}-0.291 * * * \\
0.017\end{array}$ & $\begin{array}{l}-0.340 * * * \\
0.037\end{array}$ \\
\hline Pseudo R Squared & 0.18 & 0.21 & 0.22 & 0.23 & 0.23 \\
\hline
\end{tabular}

Source Author's calculations using HIES 2009/2010, education is categorized as primary education (Grades 1-5), junior secondary (Grades 6-9), GCE O/L (Grades 10 and 11), GCE A/L (Grades 12 and 13), and tertiary (graduate or postgraduate). Standard errors are in parentheses; $*$, ** and $* * *$ indicate significance at 10,5 and $1 \%$ levels, respectively 
Table 9.8 QR estimates 2006/2007 national sample

\begin{tabular}{|c|c|c|c|c|c|}
\hline \multirow[t]{2}{*}{ Variable } & \multicolumn{5}{|l|}{ Quantile } \\
\hline & 5th & 25th & 50th & 75th & 95th \\
\hline Constant & $\begin{array}{l}7.824 * * * \\
(0.039)\end{array}$ & $\begin{array}{l}8.251 * * * \\
(0.028)\end{array}$ & $\begin{array}{l}8.551 * * * \\
(0.027)\end{array}$ & $\begin{array}{l}8.875 * * * \\
(0.031)\end{array}$ & $\begin{array}{l}9.318 * * * \\
(0.061)\end{array}$ \\
\hline $\begin{array}{l}\text { Agricultural } \\
\text { employment }\end{array}$ & $\begin{array}{l}-0.042 * * * \\
(0.015)\end{array}$ & $\begin{array}{l}-0.049 * * * \\
(0.010)\end{array}$ & $\begin{array}{l}-0.078 * * * \\
(0.010)\end{array}$ & $\begin{array}{l}-0.092 * * * \\
(0.001)\end{array}$ & $\begin{array}{l}-0.059 * * * \\
(0.021)\end{array}$ \\
\hline Number of employed & $\begin{array}{l}0.026 * * * \\
(0.000)\end{array}$ & $\begin{array}{l}0.019 * * * \\
(0.006)\end{array}$ & $\begin{array}{l}0.020 * * * \\
(0.005)\end{array}$ & $\begin{array}{l}0.011 \\
(0.006)\end{array}$ & $\begin{array}{l}-0.003 \\
(0.013)\end{array}$ \\
\hline Head's age & $\begin{array}{l}0.001 \\
(0.000)\end{array}$ & $\begin{array}{l}0.001 \\
(0.000)\end{array}$ & $\begin{array}{l}0.001 * * * \\
(0.000)\end{array}$ & $\begin{array}{l}0.001 * * * \\
(0.000)\end{array}$ & $\begin{array}{l}0.002 * * \\
(0.001)\end{array}$ \\
\hline Male head & $\begin{array}{l}0.085^{* * * *} \\
(0.015)\end{array}$ & $\begin{array}{l}0.046 * * * \\
(0.010)\end{array}$ & $\begin{array}{l}0.047 * * * \\
(0.010)\end{array}$ & $\begin{array}{l}0.026^{* *} \\
(0.002)\end{array}$ & $\begin{array}{l}0.002 \\
(0.022)\end{array}$ \\
\hline Household size & $\begin{array}{l}-0.126 * * * \\
(0.006)\end{array}$ & $\begin{array}{l}-0.139 * * * \\
(0.004)\end{array}$ & $\begin{array}{l}-0.148 * * * \\
(0.004)\end{array}$ & $\begin{array}{l}-0.152 * * * \\
(0.005)\end{array}$ & $\begin{array}{l}-0.141 * * * \\
(0.011)\end{array}$ \\
\hline Number of dependants & $\begin{array}{l}0.007 \\
(0.007)\end{array}$ & $\begin{array}{l}0.001 \\
(0.005)\end{array}$ & $\begin{array}{l}0.005 \\
(0.005)\end{array}$ & $\begin{array}{l}0.005 \\
(0.005)\end{array}$ & $\begin{array}{l}0.006 \\
(0.010)\end{array}$ \\
\hline Race: Tamil & $\begin{array}{l}-0.018 \\
(0.022)\end{array}$ & $\begin{array}{l}-0.007 \\
(0.015)\end{array}$ & $\begin{array}{l}-0.049 * * * \\
(0.014)\end{array}$ & $\begin{array}{l}-0.095 * * * \\
(0.095)\end{array}$ & $\begin{array}{l}-0.097 * * * \\
(0.030)\end{array}$ \\
\hline Race: Muslim/other & $\begin{array}{l}0.179 * * * \\
(0.026)\end{array}$ & $\begin{array}{l}0.180 * * * \\
(0.018)\end{array}$ & $\begin{array}{l}0.143 * * * \\
(0.017)\end{array}$ & $\begin{array}{l}0.149 * * * \\
(0.019)\end{array}$ & $\begin{array}{l}0.194 * * * \\
(0.035)\end{array}$ \\
\hline $\begin{array}{l}\text { Education: Jun. } \\
\text { secondary }\end{array}$ & $\begin{array}{l}0.198 * * * \\
(0.026)\end{array}$ & $\begin{array}{l}0.196 * * * \\
(0.018)\end{array}$ & $\begin{array}{l}0.170 * * * \\
(0.017)\end{array}$ & $\begin{array}{l}0.165 * * * \\
(0.020)\end{array}$ & $\begin{array}{l}0.190 * * * \\
(0.036)\end{array}$ \\
\hline Education: GCE O/L & $\begin{array}{l}0.383 * * * \\
(0.030)\end{array}$ & $\begin{array}{l}0.417 * * * \\
(0.021)\end{array}$ & $\begin{array}{l}0.423 * * * \\
(0.021)\end{array}$ & $\begin{array}{l}0.440 * * * \\
(0.023)\end{array}$ & $\begin{array}{l}0.463 * * * \\
(0.043)\end{array}$ \\
\hline Education: GCE A/L & $\begin{array}{l}0.530 * * * \\
(0.028)\end{array}$ & $\begin{array}{l}0.574 * * * \\
(0.120)\end{array}$ & $\begin{array}{l}0.604 * * * \\
(0.019)\end{array}$ & $\begin{array}{l}0.621 * * * \\
(0.021)\end{array}$ & $\begin{array}{l}0.724 * * * \\
(0.041)\end{array}$ \\
\hline Education: Tertiary & $\begin{array}{l}0.871 * * * \\
(0.037)\end{array}$ & $\begin{array}{l}0.884 * * * \\
(0.026)\end{array}$ & $\begin{array}{l}0.945 * * * \\
(0.025)\end{array}$ & $\begin{array}{l}0.963 * * * \\
(0.029)\end{array}$ & $\begin{array}{l}1.055^{* * * *} \\
(0.052)\end{array}$ \\
\hline Province:* Central & $\begin{array}{l}-0.186 * * * \\
(0.022)\end{array}$ & $\begin{array}{l}-0.192 * * * \\
(0.015)\end{array}$ & $\begin{array}{l}-0.188 * * * \\
(0.014)\end{array}$ & $\begin{array}{l}-0.189 * * * \\
(0.016)\end{array}$ & $\begin{array}{l}-0.236 * * * \\
(0.029)\end{array}$ \\
\hline Province: Southern & $\begin{array}{l}-0.054 * * * \\
(0.018)\end{array}$ & $\begin{array}{l}-0.082 * * * \\
(0.013)\end{array}$ & $\begin{array}{l}-0.101 * * * \\
(0.012)\end{array}$ & $\begin{array}{l}-0.103 * * * \\
(0.014)\end{array}$ & $\begin{array}{l}-0.169 * * * \\
(0.025)\end{array}$ \\
\hline Province: North Western & $\begin{array}{l}-0.138^{* * * *} \\
(0.023)\end{array}$ & $\begin{array}{l}-0.152 \text { *** } \\
(0.016)\end{array}$ & $\begin{array}{l}-0.157 * * * \\
(0.016)\end{array}$ & $\begin{array}{l}-0.149 \text { *** } \\
(0.017)\end{array}$ & $\begin{array}{l}-0.151^{* * * *} \\
(0.031)\end{array}$ \\
\hline Province: North Central & $\begin{array}{l}-0.142 * * * \\
(0.027)\end{array}$ & $\begin{array}{l}-0.144 * * * \\
(0.018)\end{array}$ & $\begin{array}{l}-0.153 * * * \\
(0.018)\end{array}$ & $\begin{array}{l}-0.178^{* * *} \\
(0.020)\end{array}$ & $\begin{array}{l}-0.218^{* * * *} \\
(0.037)\end{array}$ \\
\hline Province: Uva & $\begin{array}{l}-0.276^{* * * *} \\
(0.027)\end{array}$ & $\begin{array}{l}-0.293^{* * * *} \\
(0.018)\end{array}$ & $\begin{array}{l}-0.287 \text { *** } \\
(0.018)\end{array}$ & $\begin{array}{l}-0.273^{* * * *} \\
(0.020)\end{array}$ & $\begin{array}{l}0.362^{* * *} \\
(0.037) \\
\end{array}$ \\
\hline $\begin{array}{l}\text { Province: } \\
\text { Sabaragamuwa }\end{array}$ & $\begin{array}{l}-0.250 * * * \\
(0.024)\end{array}$ & $\begin{array}{l}-0.310^{* * *} \\
(0.016)\end{array}$ & $\begin{array}{l}-0.322 * * * \\
(0.016)\end{array}$ & $\begin{array}{l}-0.321 * * * \\
(0.018)\end{array}$ & $\begin{array}{l}0.377 * * * \\
(0.032)\end{array}$ \\
\hline Pseudo R Squared & 0.178 & 0.207 & 0.223 & 0.235 & 0.288 \\
\hline
\end{tabular}

Source Author's calculations using HIES 2006/2007, education is categorized as primary education (Grades 1-5), junior secondary (Grades 6-9), GCE O/L (Grades 10 and 11), GCE A/L (Grades 12 and 13), and tertiary (graduate or postgraduate). Standard errors are in parentheses; ** and *** indicate significance at 5 and $1 \%$ levels, respectively 
Open Access This chapter is distributed under the terms of the Creative Commons Attribution Noncommercial License, which permits any noncommercial use, distribution, and reproduction in any medium, provided the original author(s) and source are credited.

\section{References*}

Benjamin D, Brandt L, Giles J, Wang S (2005) Income inequality during China's economic transition. In: Brandt L, Rawski T (eds) China's great economic transformation. Cambridge University Press, Cambridge

Blinder A (1973) Wage discrimination: reduced form and structural estimates. Journal of Human Resources 18(fall):436-455

Deaton A (1997) The Analysis of Household Surveys. Johns Hopkins University Press, Baltimore

Department of Census and Statistics (1987) Labour force and Socio-Economic Survey 1985/86 final report, Colombo, Sri Lanka

Duclos J, Araar A (2006) Poverty and equity: measurement policy and estimation with DAD. Springer, New York

Fortin N, Lemieux T, Firpo S (2011) Decomposition methods in economics, In: Ashenfelter O, Card D (eds) Handbook of labor economics, vol 4a. Elsevier, Amsterdam, pp 1-102

Gunatilaka R, Chotikapanich D (2009) Accounting for Sri Lanka's expenditure inequality 19802002: regression based decomposition approaches. Rev Income Wealth 55(4):882

Heltberg R (2003) Spatial inequality in Viet Nam: a regression based decomposition. The World Bank, Washington DC

Kanbur R, Venables A (2005) Spatial inequality and development. J Econ Geogr 4(2)

Koenker R, Bassett G (1978) Regression quantiles. Econometrica 46(1):33-50

Kumara T (2012) Decomposing spatial inequality in Sri Lanka: a quantile regression analysis, research paper presented at the 4 th international development conference, organized by the University of Bordeaux, France from 13th to 15th of June in Bordeaux, France

Kumara T (2009) Decomposition of published M.Phil. thesis, Department of Economics and Statistics, University of Peradeniya, Sri Lanka

Machado J, Mata J (2005) Counterfactual decompositions of changes in wage distributions using quantile regression. J Appl Econ 20(4):445-465

Martins PS, Pereira P (2004) Does Education reduce wage inequality? Quantile regression evidence from 16 countries. Labour Econ 11(3):355-371

Melly B (2005) Public-private sector wage differentials in Germany: evidence from quantile regressions. Empirical Econ 30:505-520

Nguyen BT, Albrecht JW, Vroman BS, Westbrook MD (2006) A quantile regression decomposition of urban-rural inequality in Viet Nam. J Dev Econ 83(2):466-490

Oaxaca R (1973) Male-female wage differentials in urban labor markets. Int Econ Rev 14(October):693-709

Ravallion M (2005) Inequality is bad for the poor, World Bank policy research working paper 3677, The World Bank, Washington DC

Wan GH (2002) Regression-based Inequality decomposition: pitfalls and a solution procedure, Discussion paper no. 2002/101, WIDER, United Nations University

Wan GH (2007) Understanding regional poverty and inequality trends in People's Republic of China: methodological issues and empirical findings. Rev Income Wealth 53(1):25

World Bank (2004) Sri Lanka Development Policy Review, Report No 29396, Washington DC

\footnotetext{
* ADB recognizes "China" as the People's Republic of China.
} 
World Bank (2005a) World Development Report 2006: Equity and Development, Washington DC World Bank (2005b) Attaining the millennium development goals in Sri Lanka, Washington DC World Bank (2007a) Sri Lanka development forum: the economy, regional disparities and global opportunities, Colombo

World Bank (2007b) Sri Lanka poverty assessment, Report no. 36568-LK, Washington DC

World Bank (2008) World development report 2009: reshaping economic geography, Washington DC 